\title{
Ikke fast oksygen til kolspasienter
}

Oksygentilskudd på fast basis til pasienter med kronisk obstruktiv lungesykdom og moderat redusert oksygenmetning gir verken bedre prognose, helsetilstand eller livskvalitet. Det viser en ny studie.

I en randomisert, kontrollert studie er effekten av langtidstilskudd av oksygen hos pasienter med kronisk obstruktiv lungesykdom (kols) og moderat redusert oksygenmetning under-

søkt (1). Studien omfattet 738 pasienter med en oksygenmetning på $89-93 \%$ i hvile eller moderat redusert oksygenmetning ved seks minutters gangtest. Pasientene ble randomi-

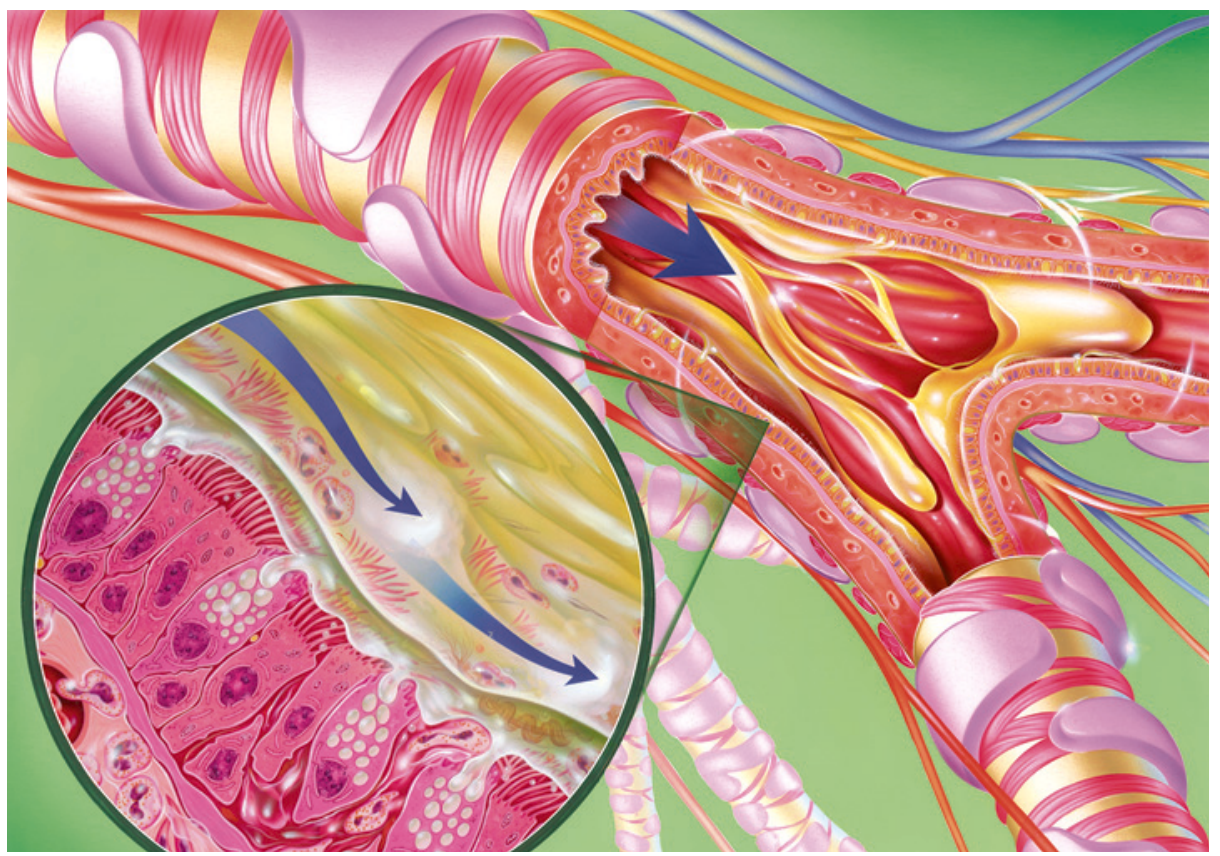

Bronkiene hos en kolspasient. Foto: Science Photo Library sert til bruk eller ikke-bruk av fast oksygentilskudd, enten hele døgnet eller mens de sov eller var i fysisk aktivitet.

Etter tre år (median) var det ingen signifikante forskjeller mellom de to gruppene $\mathrm{i}$ mortalitet, tidsintervall til sykehusinnleggelse, forverring av kolssykdommen, livskvalitet, lungefunksjon eller ganglengde i seks minutter. Det var heller ingen forskjeller i forekomsten av angst eller depresjon. Blant pasientene som fikk oksygentilskudd, var det totalt 51 tilfeller av negative effekter, hvorav 23 skyldtes fall etter å ha snublet i utstyret.

En av svakhetene ved studien er at pasienter som allerede brukte oksygentilskudd med god opplevd effekt, kan ha sagt nei til deltagelse og dermed bidratt til skjevhet i utvalget. Studien var også basert på selvrapportert oksygenbruk og selvrapportert sykdomsforverring. Med tanke på at kols er en kronisk sykdom mange lever med $i$ årevis, kan det også være at resultatene ville blitt annerledes med lengre oppfølgingstid.

Forfatterne konkluderer med at det ikke er noen helsegevinst $\mathrm{i}$ å gi oksygentilskudd til kolspasienter med moderat redusert oksygenmetning.

\section{Matilde Risopatron Berg}

Sykehuset Innlandet, Hamar

\section{Litteratur}

1. Albert RK, Au DH, Blackford AL et al. A randomized trial of long-term oxygen for COPD with moderate desaturation. N Engl J Med 2016; 375: 1617-27.

\section{Sunn livsstil reduserer høy risiko for hjertesykdom}

\author{
De som er genetisk disponert for \\ hjertesykdom, kan redusere risi- \\ koen betraktelig ved en sunn livs- \\ stil, viser ny studie.
}

Både genetiske forhold og livsstil har betydning for utvikling av hjerte- og karsykdom. Hvor mye betyr livsstilen dersom man allerede er familiært disponert for å utvikle slik sykdom?

Risikoen for hjertesykdom ble bestemt prospektivt i tre kohorter, to fra USA og én fra Sverige, og i én amerikansk tverrsnittsstudie (1). Til sammen omfattet de fire studiene nesten 56000 personer. Genetisk risiko ble bestemt ved en risikoskår basert på opptil 50 enkeltnukleotidpolymorfismer som tidligere er vist å være assosiert med hjerte- og karsykdom. Deltagernes livsstil ble vurdert på grunnlag følgende faktorer: ingen røyking, ingen fedme, regelmessig fysisk aktivitet og sunn diett. Gunstig livsstil ble definert som bekreftende svar på spørsmål om minst tre av disse faktorene.

Personer med høy genetisk risiko for hjerte- og karsykdom hadde 91\% høyere relativ risiko for koronare hendelser (HR 1,91; $95 \%$ KI 1,75-2,09). Hos høyrisikoindividene var en gunstig livsstil assosiert med $46 \%$ lavere relativ risiko for koronare hendelser (HR 0,54; $95 \%$ KI 0,47-0,63). I tverrsnittsstudien var en gunstig livsstil assosiert med signifikant mindre aterosklerose i koronarkar ved både lav, middels og høy genetisk risiko.

- Denne studien tilfører viktig ny kunnskap, sier Kjetil Retterstøl, professor ved Avdeling for ernæringsvitenskap, Universitetet i Oslo, og overlege ved Lipidklinikken, Oslo universitetssykehus. - For det første viser den at det er mulig å identifisere personer med høy risiko for hjerte- og karsykdom ved såkalt villscreening. Dette er viktig fordi vi nå har effektive virkemidler for å forebygge slik sykdom. For det andre belyser studien et fenomen som fortjener økt oppmerksomhet, nemlig at sunn livsstil er ekstra viktig for dem som er født med økt genetisk risiko for aterosklerose, sier han.

- Studien viser også at man på et generelt befolkningsnivå nå er i stand til å gruppere i høy versus lav risiko for hjerte- og karsykdom med en styrke som er av klinisk betydning. Det er gammelt nytt når det gjelder livsstil, men ikke når det gjelder utregnet polygen risiko, sier Retterstøl.

\footnotetext{
Kari Tveito

Tidsskriftet

Litteratur

1. Khera AV, Emdin CA, Drake I et al. Genetic risk adherence to a healthy lifestyle, and coronary disease. N Engl J Med 2016. E-publisert 13.11.2016. http://www nejm.org/doi/full/10.1056/ NEJMoa1605086?cookieSet=1 (25.11.2016).
} 